\title{
Modeling of Spray Characteristics of Biodiesel Based on Vegetative Energy Resources Found in Tropical Forest Inside Leuser Area
}

\author{
Teuku Azuar Rizal ${ }^{1, *}$ Hamdani $^{1}$ Taufan Arif Adlie ${ }^{1}$ \\ ${ }^{1}$ Department of Mechanical Engineering, Universitas Samudra, 24416, Indonesia \\ *Corresponding author. Email: azuarrizal@unsam.ac.id
}

\begin{abstract}
The depleting reserves of fossil fuels encourage the arrangement of biodiesel as an increasingly popular alternative. The energy is also more environmentally friendly, and at the same time, low in emission content. The biodiesel feedstock source is also easily found in Indonesia's tropical forests, yet many research types are still required to reveal biodiesel's detailed characteristics in an internal combustion engine. Therefore, this research tries to contribute to investigating the behavior of biodiesel spray inside the combustion chamber. The analysis utilizes software Diesel RK to perform a computer simulation that will show biodiesel spray behavior. The simulation result depicts that biodiesel's density and kinematic viscosity contribute inversely to biodiesel spray's desired model. This research delivers an alternative point of view related to unique Indonesian biodiversity related to energy issues. The rain forest can become a highly potential complementary energy resource. It provides the local community with a different energy buffer as a stock of a relatively close energy source.
\end{abstract}

Keywords: Modeling, Spray-Characteristics, Biodiesel, Vegetative-Energy-Resources, Diesel-RK.

\section{INTRODUCTION}

In recent years, Indonesia has had many trials associated with legal and illegal threats to forests and their biodiversity, including in Aceh's forests-Leuser ecosystem, home to one of the vital forest reserves [1]. There significant evidence that kinematic viscosity is lowering due to the increase in temperature [2]. Liquid biofuels have been likely endorsed as future transportation energy. Hence, second-generation biofuels' production using lignocellulosic feedstocks, such as forest-based biomass, is expected to increase globally. Forest biomass abundance and experience with applying biomass conversion technologies give the Nordic countries an advantage in catering to biofuel production capacity investment [3].

Generally, Bio-oil and biodiesel for industrial use were made of tallow, an animal-fat by-product, or transesterification of waste cooking oil [4], [5]. Due to the change of perception of most consumers and the intention to reduce environmental harm from fossil fuel, plant-based bio-oil/biodiesel demand increases. Which, in turn, unintentionally creates massive destruction to the remaining forest in the tropical country. European Union (E.U.) palm oil imports shot up $15 \%$ the year after the RED, reaching an all-time high, and 19\% the year after that, as biofuel use tripled in the E.U. between 2011 and 2014; palm oil's share of biofuel raw material leaped fivefold in that period. Half of the E.U.'s palm oil now goes to biofuel, double the claim before the RED. Sustainability criteria were later added - although Oxfam and others have criticized their effectiveness, European commissioners proposed new limits on biofuel crops tied to deforestation. However, the damage had already taken place [6].

Most of the forest in Papua, Kalimantan, Sumatera has been converted into palm plantation as shown in Fig 1. Recently, a group of researchers from the University of London's Forensic Architecture group and Greenpeace released shocking evidence that accused a giant South Korean company of deliberately using fire to clear land for palm plantation. the footage shows in local media depict a considerable loss of biodiversity [7]. 


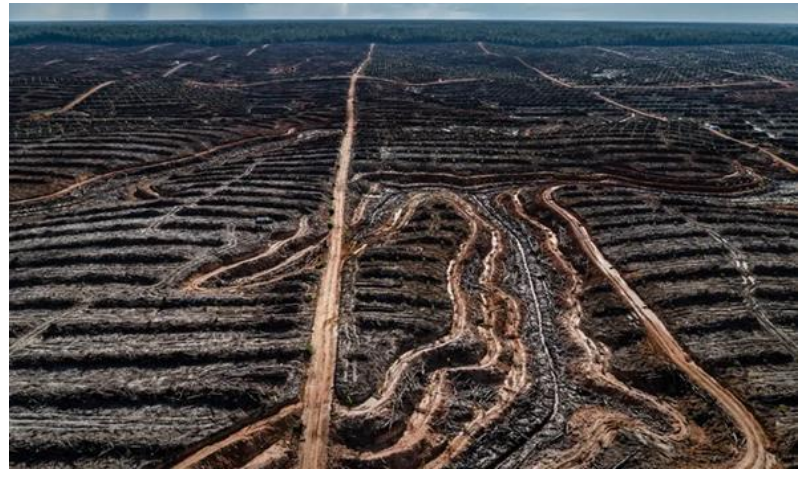

Figure 1 A visual investigation released on Thursday (12/11) showed a giant South Korean company "deliberately" using fire to clear Papua's forests to expand palm oil land [8].

From the previous section, we can understand that there are so many questions that have been raised. Why sacrifice rich biodiversity to palm monoculture? Can we use the forest as a sustainable source of energy? Is there any plant that originated from the forest that can be used as biofuel feedstock? How does it perform in the engine? Etc. It is ranged from biodiversity issues to the performance of local grade biodiesel application the engine. Unfortunately, this research cannot cope with all the questions.

Nevertheless, we will try to find the closest solution to the overlapping problem forest already provide abundant energy resources. By applying conversion technologies currently available, we can turn it into a sustainable benefit (i.e., biomass conversion into biofuel technology, transesterification of fatty acid in the specific plant). In this case, previous research has already shown that several feedstocks originated from the forest and already turned into biodiesel. Therefore, this research's focus will be limited to biodiesel's performances from a local plant that hopefully can gain awareness of the forest as a future source of sustainable energy resource.

\section{METHOD}

The method used in this research is numerical analysis/simulation. The local fruit is known as Pangee in local terms, or kluwek and picung in some ether part of the region, also known as Kepayang or in Latin, written as Pangium Edule Reinw [9]. This fruit is commonly found in the local forest and is known to be ready to harvest twice a year. It has already been identified as a potential local biodiesel feedstock, which the local community has already used as cooking oil. This raw oil is then extracted into biodiesel by transesterification process and followed by assorted analysis. Parameter found during the investigation is then entering the simulation setup.

In this modeling of spray characteristics of biodiesel, the simulation is conducted with Diesel RK software. The software can predict and optimize fuel consumption, analyze the combustion and emission, analyze dual-fuel engine mixture formation and combustion, predict knock, optimize valve timing, and convert diesel engines into gas engines. The most convenient feature of this application is the capability to cooperate with different modeling tools such as Simulink, IOSO NM. The solver can be run under the control of other applications. Last but not least, it is free.

This research has been conducted through series of procedures; they are (i) rapid assessment of local biodiesel feedstock via literature review, (ii) extracting the oil, (iii) transesterification into biodiesel, (iv) Gas Chromatography-Mass Spectrometry (GCMS) analysis, (v) fundamental physicochemical analysis of biodiesel, and (vi) Running the Simulation of Biodiesel in an Internal Combustion Engine.

\section{RESULT AND DISCUSSION}

Several parameters have been collected and compiled in Table 1. Some parameters are obtained from the direct analysis and literature review, while others were adjusted regarding the closest properties with other biodiesel in the software library.

Table 1. Fuel input parameter for Pangium biodiesel [10]-[13]

\begin{tabular}{lc}
\hline Parameter & $\begin{array}{c}\text { Pangium } \\
\text { Biodiesel }\end{array}$ \\
\hline Calorific value (M.J./kg) & 39.91 \\
API gravity (specific gravity: 0.866) & 31.90 \\
Kinematic viscosity at 40 oC (cSt) & 4.90 \\
Cloud point (oC) & 16.00 \\
Pour point (oC) & 15.00 \\
Flashpoint (oC) & 172.5 \\
Fire point $(\mathrm{oC})$ & 331.00 \\
Conradson carbon residue $(\%, \mathrm{w} / \mathrm{w})$ & 0.30 \\
Ash content $(\% \mathrm{w} / \mathrm{w})$ & 0.0066 \\
Nitrogen $(\% \mathrm{w} / \mathrm{w})$ & 0.00 \\
Carbon $(\% \mathrm{w} / \mathrm{w})$ & 0.1882 \\
Hydrogen $(\% \mathrm{w} / \mathrm{w})$ & 0.3439 \\
Oxygen $(\% \mathrm{w} / \mathrm{w})$ & 0.02 \\
Sulfur $(\% \mathrm{w} / \mathrm{w})$ & 0.04 \\
LHV of Fuel $[\mathrm{MJ} / \mathrm{kg}]$ & 37.00 \\
Cetane Number & 52.00 \\
Density at 323oK $(\mathrm{kg} / \mathrm{m} 3)$ & 879.3 \\
Surface Tension of Fuel at 323 K [N/m] & 0.0301 \\
Fuel temperature $[\mathrm{K}]$ & 293 \\
\hline
\end{tabular}

\subsection{Simulation Setup}

The simulation was conducted throughout several essential steps, begin with engine parameter setups such as engine stroke and fuel selection, as shown in Fig.2. Step 2, as depicted in Fig. 3, the general parameter set up 
according to the manufacture datasheet, i.e., cylinder bore, piston stroke, compression ratio, average engine speed; Step 3, setting up the Fuel Injection System and combustion chamber, Fig 4. It shows that it was setting as default. Fig. 5 shows a detail of step 4, setting up the

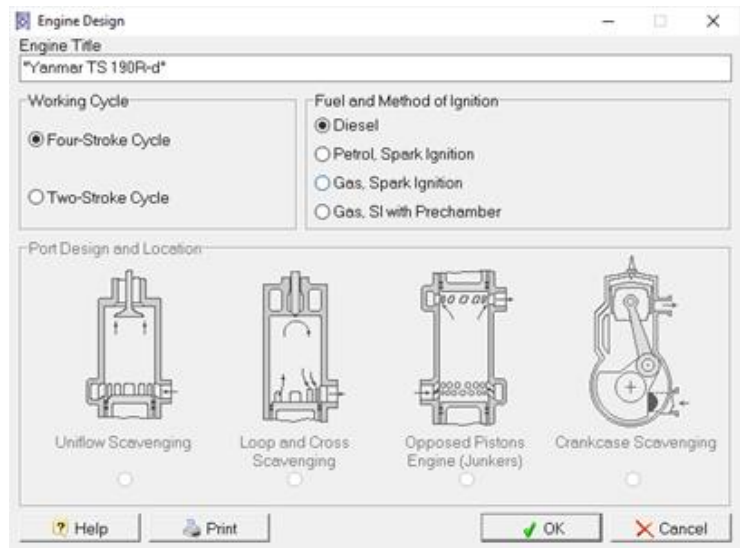

Figure 2 Step 1, engine design

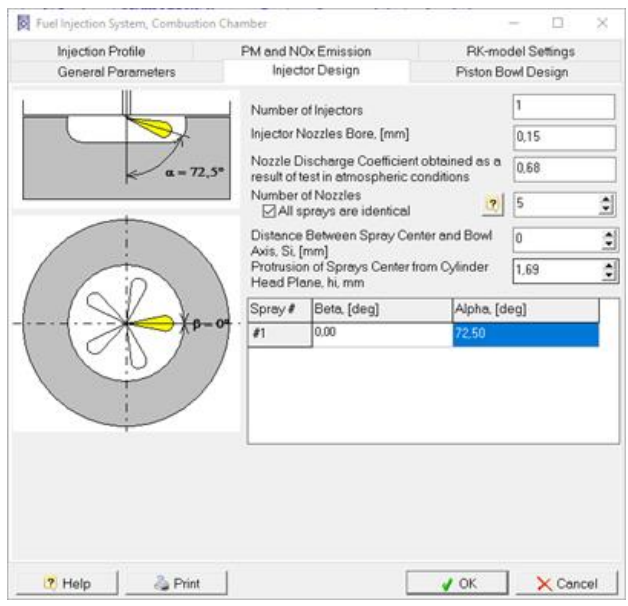

fuel parameters resulting from the previous analysis shown in table 1. Step 5, as depicted in Fig. 6, sets up the operating mode. In this study, two types of fuel run in two types of operational rpm mode, i.e., 1000 vs. $2200 \mathrm{rpm}$.

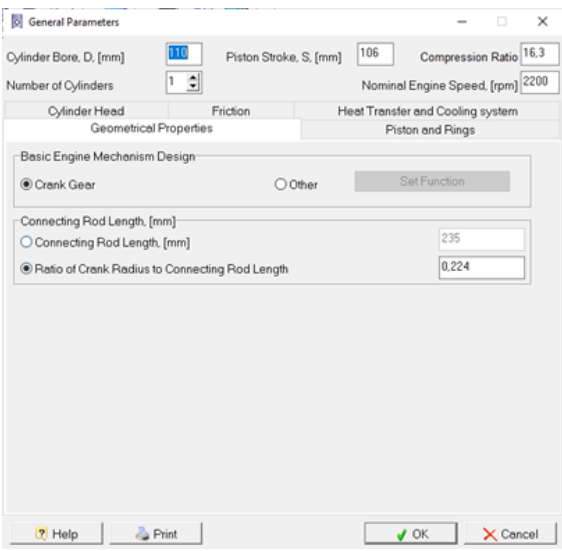

Figure 3 Step 2, Cylinder design

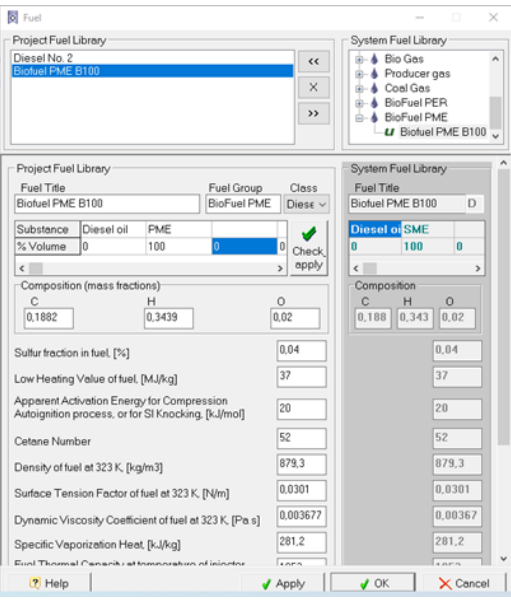

Figure 5 Interface of fuel parameter

Figure 4 Step 3 , Int
combustion chamber

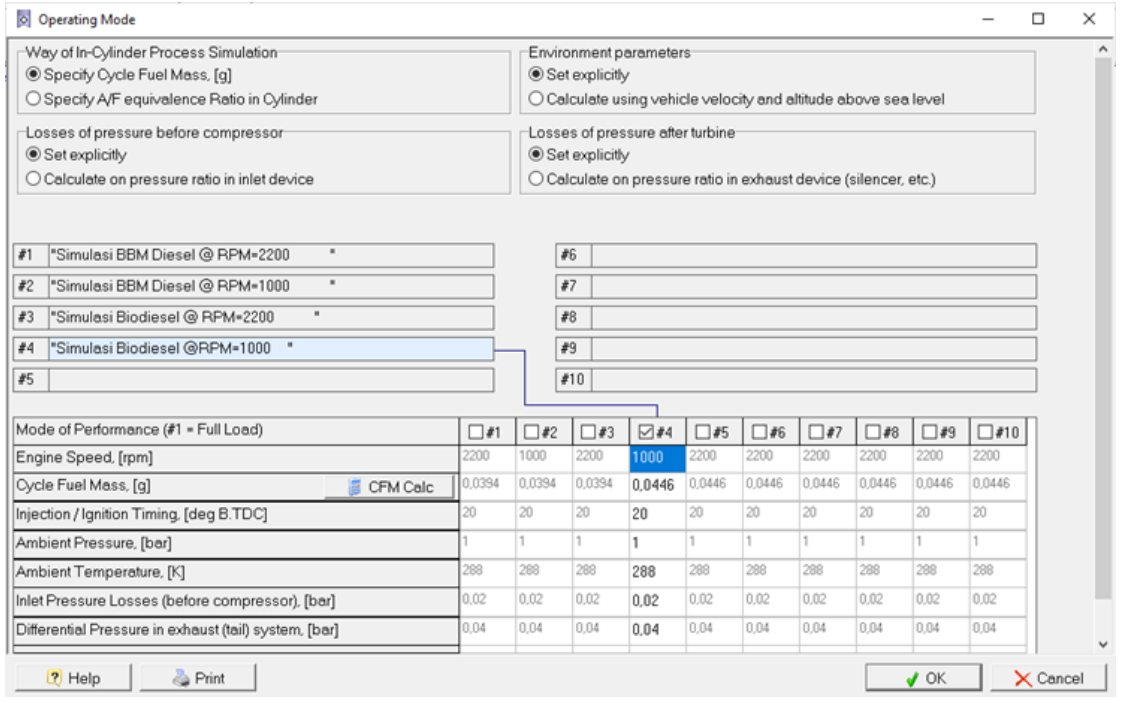

Figure 6 The Interface of Operating mode 


\subsection{Results of Simulations}

After simulating at $1000 \mathrm{rpm}$ and $2000 \mathrm{rpm}$, both modes show that biodiesel performs a relatively superior performance. It is relatively easy to increase its pressure and, therefore, the temperature. Fig. 7 and 8 depict the heat release rate and cylinder pressure of biodiesel and commercial diesel.

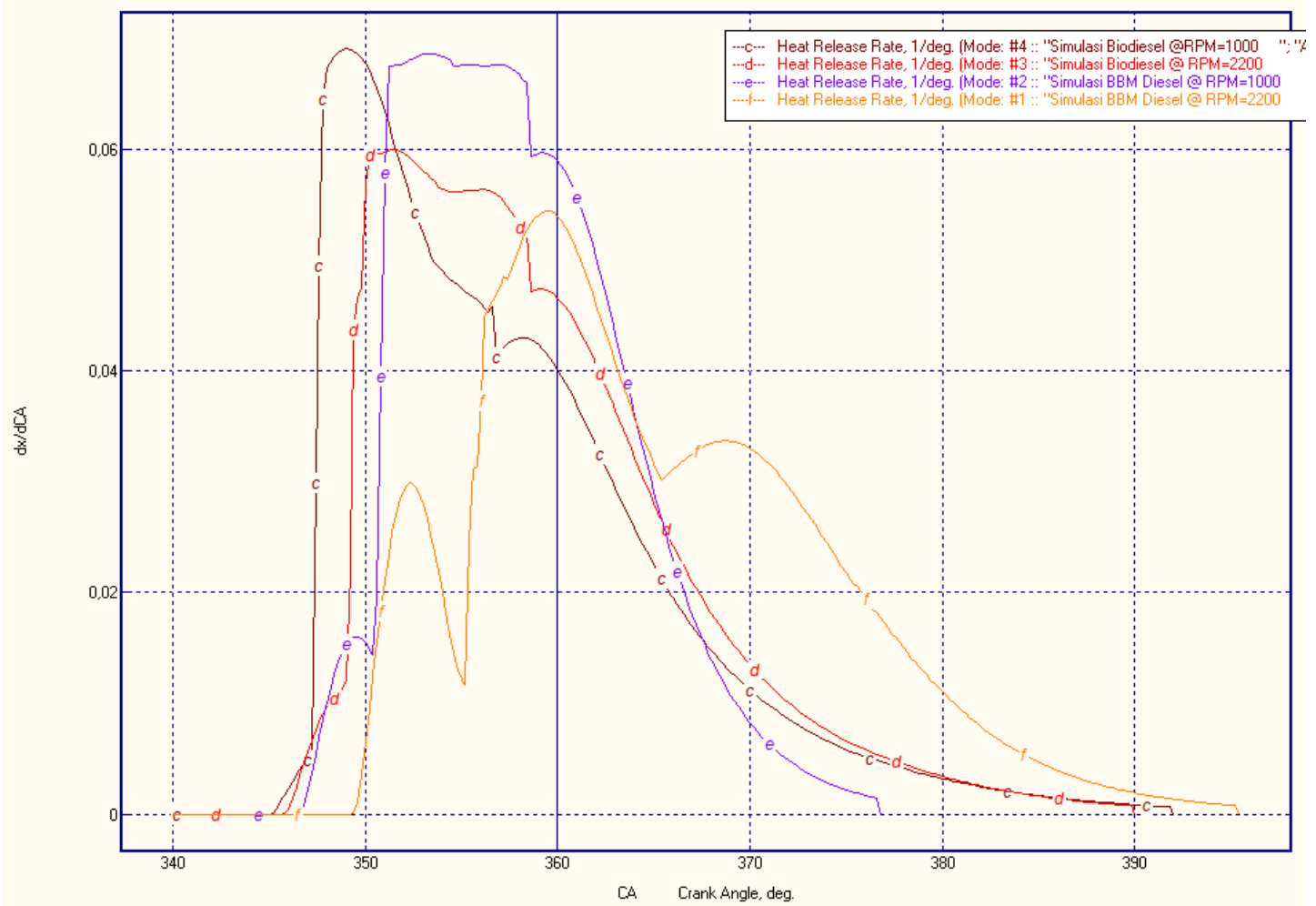

Figure 7 dx/dCA (Heat Release Rate)

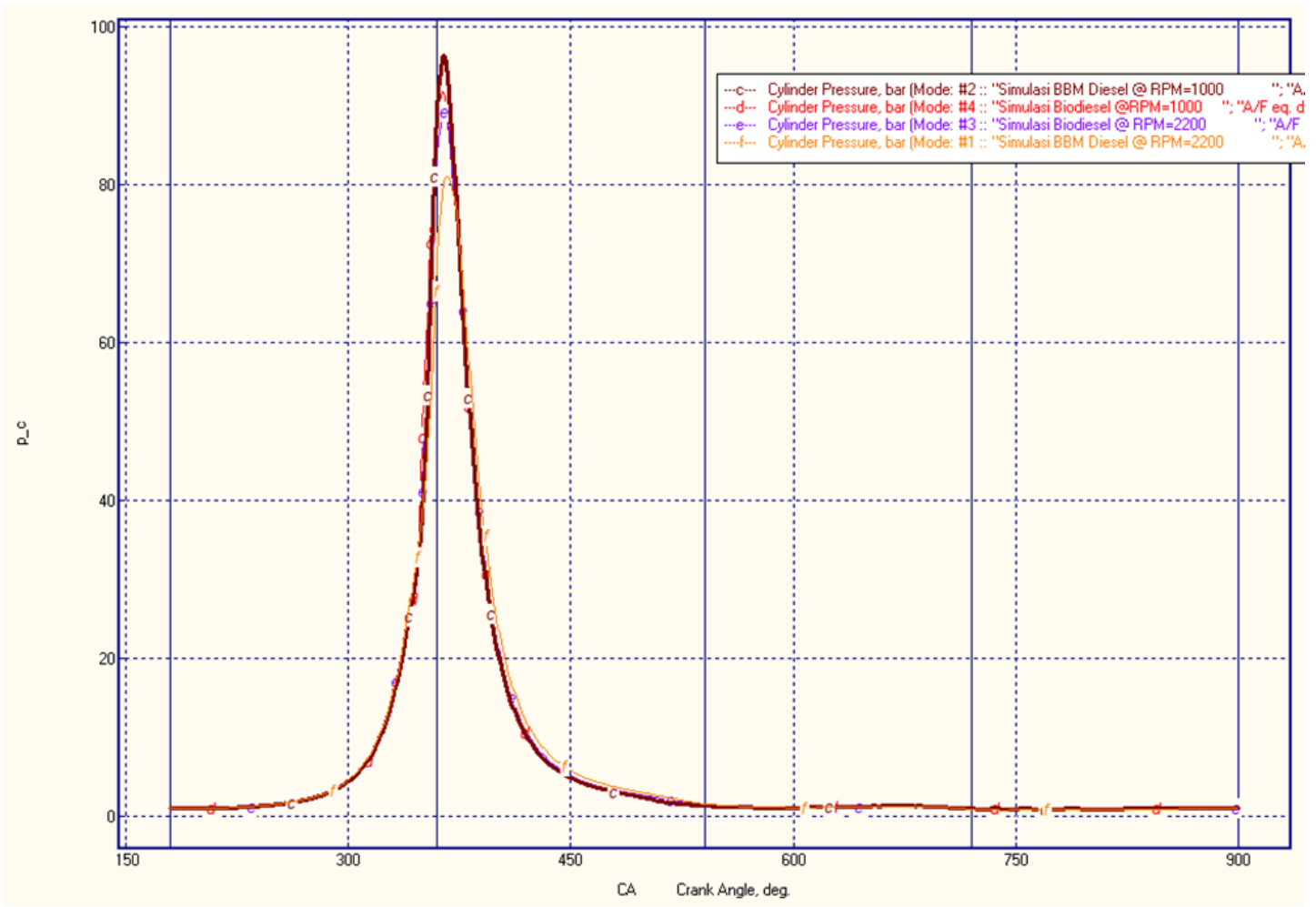

Figure 8 P_c (Cylinder Pressure). 


\subsection{Discussion}

Biodiesel shows a slightly higher heat release rate $(\mathrm{dx} / \mathrm{dCA})$ and pressure in the cylinder, which helped the fuel beam's vaporization quality. In both rpm modes, the $\mathrm{dx} / \mathrm{dCA}$ shows a higher value. This capability indicates that biodiesel performs better in terms of spray formation inside the combustion chamber. However, the result might become different if the detailed parameter of fuel is modified or enhanced. Fig. 9 shows the differences in spray formation inside the combustion chamber.

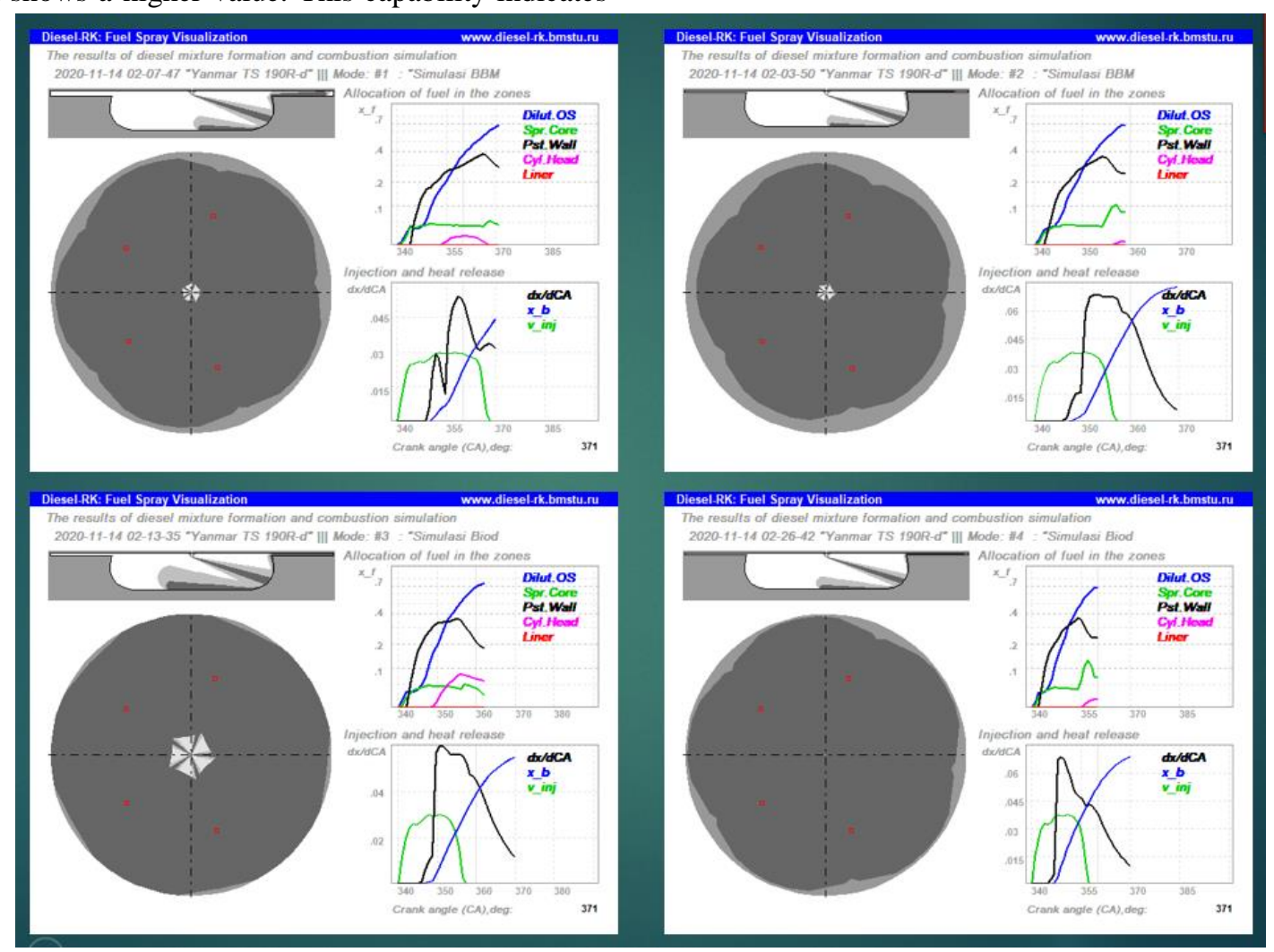

Figure 9 Comparison of the spray behavior of biodiesel compared to commercial diesel

\section{CONCLUSION}

The local forest plant identified as biodiesel feedstocks is Pangium Edule/Kepayang/Kluwek/Picung or Pangé. With a currently available parameter, the simulation shows that the biodiesel is assumed suitable for a direct injection diesel engine up to $100 \%$ (B100) and offers nearly equal performance to conventional diesel fuel. Biodiesel simulates a higher heat release rate and higher cylinder pressure both in 1000 and 2200 RPM. This fuel has shown relatively better performance and might seem promising as an alternative source of fuel. Nevertheless, as a consideration, there is still some void in the parameters during this simulation. Some of the fuel properties should be refined and validated. Therefore, to enhance the simulation result, more detailed research particularly related to the fuel's properties must be conducted.

Furthermore, the local community should have been benefited from this resource. Up to this date, only a few people already know and still used these sources as cooking oil, but the knowledge seems to fade away due to palm oil's massif use. Due to its potential as an alternative source of biodiesel, it is clear that the energy source's diversification is a must, not only a choice. In the future, local people should consider preserving the knowledge of using this gift as a local source of energy.

\section{ACKNOWLEDGMENTS}

This research has been conducted under Penelitian Dasar Unggulan (PDU) scheme, funded from DIPA Universitas Samudra year 2020 contract No. 555/UN54.6/PG/2020.

\section{REFERENCES}

[1] R. Rosemary and D. Evensen, "Unveiling the 'green': Media coverage on the aceh green vision, indonesia," in Springer Climate, Springer Science and Business Media B.V., 2021, pp. 281-300.

[2] S. Z. Razali, R. Yunus, S. Abdul Rashid, H. N. Lim, and B. Mohamed Jan, "Review of biodegradable synthetic-based drilling fluid: Progression, performance and future prospect," Renewable and Sustainable Energy Reviews, vol. 90, pp. 171-186, Jul. 2018, doi: 10.1016/j.rser.2018.03.014. 
[3] W. F. Mustapha, E. Trømborg, and T. F. Bolkesjø, "Forest-based biofuel production in the Nordic countries: Modelling of optimal allocation," Forest Policy and Economics, vol. 103, pp. 4554, Jun. 2019, doi: 10.1016/j.forpol.2017.07.004.

[4] D. Ayu, R. Aulyana, E. W. Astuti, K. Kusmiyati, and N. Hidayati, "Catalytic Transesterification of Used Cooking Oil to Biodiesel: Effect of OilMethanol Molar Ratio and Reaction Time," Automotive Experiences, vol. 2, no. 3, pp. 73-77, 2019, doi: 10.31603/ae.v2i3.2991.

[5] A. Kolakoti, M. Setiyo, and B. Waluyo, "Biodiesel Production from Waste Cooking Oil : Characterization, Modeling and Optimization 2 . Material and Methods," Mechanical Engineering for Society and Industry, vol. 1, no. 1, pp. 22-30, 2021, doi: 10.31603/mesi.5320.

[6] Global Conservation, "Leuser Ecosystem, Sumatra, Indonesia | Our Projects | Global Conservation," leuser-national-park-indonesia, 2020. .

[7] A. J. Iswara, "Investigasi Ungkap Perusahaan Korsel Bakar Hutan Papua untuk Perluasan Lahan Sawit," kompas.com, 2020.

[8] Mongabay, "Palm oil giant Korindo accused again of illegally burning Papuan rainforest."
[9] F.-H. I, N. Idris, and J. Liam, "New Materials for our Industries: PANGIUM EDULE REINW. (Kepayang) - Any Takers for Development of Products?," Synstesis, no. 16, p. 16, 2007.

[10] Khairil, S. Thalib, and Turmizi, "Fundamental Study of Diesel Engine Performance by Implementing Oil from Tropical Kepayang Seeds (Pangium edule)," Advanced Materials Research, vol. 1115, pp. 480-483, Jul. 2015, doi: 10.4028/www.scientific.net/AMR.1115.480.

[11] A. E. Atabani, I. A. Badruddin, H. H. Masjuki, W. T. Chong, and K. T. Lee, "Pangium edule Reinw: A Promising Non-edible Oil Feedstock for Biodiesel Production," Arabian Journal for Science and Engineering, vol. 40, no. 2, pp. 583594, 2014, doi: 10.1007/s13369-014-1452-5.

[12] Nofiarli, K. Anwar, and N. Hazli, "The Biodiesel characteristic of kepayang oil (Pangium edule Reinw)," WSEAS Transactions on Biology and Biomedicine, vol. 11, no. 3, pp. 15-19, 2014.

[13] T. A. Rizal, H. Hamdani, R. Thaib, K. Khairil, H. Husin, and M. Mahidin, "Thermodynamic performance investigation of a diesel engine running on biodiesel derived from pangium edule and cocos nucifera," Journal of Physics: Conference Series, vol. 1402, p. 044040, Dec. 2019, doi: 10.1088/1742-6596/1402/4/044040. 